\title{
DIFFERENTIAL SUBORDINATION AND SUPERORDINATION OF ANALYTIC FUNCTIONS DEFINED BY THE MULTIPLIER TRANSFORMATION
}

\author{
Rosihan M. Ali, V. Ravichandran AND N. SEENIVASAgan
}

\begin{abstract}
Differential subordination and superordination results are obtained for analytic functions in the open unit disk which are associated with the multiplier transformation. These results are obtained by investigating appropriate classes of admissible functions. Sandwich-type results are also obtained.
\end{abstract}

Mathematics subject classification (2000): 30C80, 30C45.

Keywords and phrases: Subordination, superordination, multiplier transformation, convolution.

\section{REFERENCES}

[1] R. Aghalary, R. M. Ali, S. B. Joshi And V. RaVichandran, Inequalities for analytic functions defined by certain linear operator, Internat. J. Math. Sci, 4(2) (2005), 267-274.

[2] R. M. ALI, V. RAVICHANDRAN AND N. SEENIVASAGAN, Differential subordination and superordination for meromorphic functions defined by multiplier transformations, preprint.

[3] R. M. Ali, V. RaVICHANDRAN AND N. SEENIVASAGan, Differential subordination and superordination for meromorphic functions defined by Liu-Srivastava linear operator, Bull. Malays. Math. Sci. Soc. (2), 31 (2) (2008), 193-207.

[4] R. M. Ali, V. RAVICHANDRAN AND N. SEENIVASAgan, Differential subordination and superordination for analytic functions defined by the Dziok-Srivastava linear operator, preprint.

[5] M. K. Aouf, H. M. Hossen AND A. Y. Lashin, An application of certain integral operators, J. Math. Anal. Appl. 248(2) (2000), 475-481.

[6] N. E. CHO AND H. M. SRIVASTAVA, Argument estimates of certain analytic functions defined by a class of multiplier transformations, Math. Comput. Modelling 37(1-2) (2003), 39-49.

[7] N. E. CHO AND T. H. KIM, Multiplier transformations and strongly close-to-convex functions, Bull. Korean Math. Soc. 40(3) (2003), 399-410.

[8] Y. C. KIM AND H. M. SRIVASTAVA, Inequalities involving certain families of integral and convolution operators, Math. Inequal. Appl. 7(2) (2004), 227-234.

[9] S. S. Miller And P. T. Mocanu, Differential Subordinations, Dekker, New York, 2000.

[10] S. S. Miller AND P. T. Mocanu, Subordinants of differential superordinations, Complex Var. Theory Appl. 48(10) (2003), 815-826.

[11] G. Ş. SĂLĂGEAN, Subclasses of univalent functions, in Complex analysis-fifth Romanian-Finnish seminar, Part 1 (Bucharest, 1981), 362-372, Lecture Notes in Math., 1013, Springer, Berlin.

[12] H. M. SRIVASTAVA, Some families of fractional derivative and other linear operators associated with analytic, univalent, and multivalent functions, in Analysis and its applications (Chennai, 2000), 209-243, Allied Publ., New Delhi.

[13] B. A. Uralegaddi AND C. Somanatha, Certain classes of univalent functions, in Current topics in analytic function theory, 371-374, World Sci. Publishing, River Edge, NJ. 